A Concise History of Chemistry, written in his early years, while the later ones were Industrial Catalysis and Industrial Fats and Waxes.

Hilditch was elected a Fellow of the Royal Society in 1952. He was also a Fellow of the Chemical Society and the Royal Institute of Chemistry, and a member of the Society of Chemical Industry: he served the last two Societies as a council member and as vice-president. Up to the end of his life he continued to give groat service to their Liverpool sections, by whom he will be greatly missed.

Hilditch was frequently consulted by Government bodies, and for his services to the Colonial Products Research Council he was awarded the C.B.E. in 1952.

During his retirement he received many other honours. In 1962 the Lampitt Medal from the Society of Chemical Industry, in 1964 the Chevreul Medal from the Groupement Technique Des Corps Gras, France, and this year the American Oil Chemists' Society held in his honour a spocial symposium on "Glycerides", and their North Central Group gave him the Alton E. Bailey Award. Unfortunately, Prof. Hilditch was unable to receive these last two personally.

At a first meoting with Hilditch, even in his younger days, one had the immediate impression of a highly disciplined man with authority and of a somewhat austere mien, but on longer acquaintance something would occur to produce that kindly smile by which all his old friends affectionately remember him. The affection in which he was held was evinced by the many visitors to his home, particularly old students, and the honour which they felt when in turn he visited them, as he frequently did.

Hilditch always put his energies first into the duties of his position at the time, whether as student, industrial research chemist, or professor, but he was not without outside interests. He delighted in working in his garden or watching a cricket match and for many years served All Saints Church, Oxton, as churchwarden. It was at this ehurch that the final tribute was paid to him in the presence of a large number of his former colleagues, students and friends.

His widow, who greatly helped him in his work, survives him, and also three married daughters of a previous marriage.

P. N. Williams

\section{Prof. C. B. Purves}

Prof. Clifford B. Purves, chairman of the Department of Chemistry, McGill University, Montreal, died on Septomber 30. As E. B. Eddy professor of industrial and cellulose chemistry he was also head of the Wood Chemistry Division of the Pulp and Paper Research Institute of Canada.

He leaves a widow, three sons, and three daughters.

Although honours embarrassed him, Dr. Purves's distinction as an educator and scientist was recognized. through the award of two honorary degrees, one from Lawrence College, Appleton. Wisconsin (1944), and the other from Windsor University, Windsor, Ontario (1964). In 1960 the Chemical Institute of Canada, of which he had been president in 1956-57, presented him with its medal for distinguished servico to the sciences of chemistry and chemical engineering in Canada. The American Chemical Society, in 1963, honoured him with the Ansolme Payen Award for his contributions to the field of wood chemistry.

Dr. Purves was a man of modesty, warmth, generosity, fairness and inflexible honesty. Though he never failed to remember important things, true to the character of a professor he was absent-minded about trivia and often. made his absent-mindedness the butt of his own wit. His sense of humour was strong; he had a large fund of anecdotes, always apt to the occasion, and, unlike many professors, he never ruined their point in the telling.
His strongest personal characteristic was concern. He was always concerned about each of his colleagues and students as individuals and, however busy he may have been, he never turned away a caller who might be troubled by a problem, personal or scientific. He always helped to the utmost of his power and probably felt his deepest frustrations on those occasions when his help was to no avail.

His concern extended far beyond his immodiate colleagues to the profession of chemistry in general. His active participation in the Corporation of Professional Chemists of Quebec (he was its president in 1964) arose from his foeling of the need to strengthen the position of chemists as professionals.

Outside the realm of chemistry, Dr. Purvos had other concerns. In his Convocation Address at the University of Windsor he spoke fervently of the need for educators, in their anxiety to cater for the demands of college-oriented youngsters of $I Q 110$ and higher, who constitute only 20-30 per cent of the general population, not to overlook the plight of the 20 per cent of $I Q$ less than 80. He felt that in an increasingly technological society the lives of these latter people were becoming more and more aimless, and devoid of satisfactions.

In his Anselme Payen Award Lecture in 1963, Dr. Purves had also spoken of education. He felt that the greatest single deficiency of modern primary education in North Amorica was its failure to teach elementary arithmetic, and he held up the Scottish education system as a model to be followed.

Born and educated in Scotland, Dr. Purves went to Canada in 1943 to succeed Prof. Harold Hibbert on the latter's retirement from the chair of industrial and cellulose chemistry. He arrived well prepared, having obtained his doctorate in 1929 in the field of earbohydrate chemistry under Sir James Irvine. During 1926-29 he had also worked as a Commonwealth Fund Fellow attached to the Polarimetric Division of the U.S. Bureau of Standards, in Washington, D.C., where C. S. Hudson had been his chief.

After two more years in Scotland, Dr. Purves moved to the United States in 1931, and became a research associate at the Chemical Foundation of Now York (now the U.S. National Institutes of Health). During 1936-43 he was an associate professor of organic chemistry in the Massachusetts Institute of Technology.

At McGill, he built a strong research group, and continued his investigations of the chomistry of carbohydrates. A large part of his work was directed at the location of substituents in such cellulose derivatives as the acetates, xanthates and nitrates (see Chemistry in Canada, 25-29; December 1960). During this period he also began to interest himself in the lignin component of wood, and in 1947 published a method for the isolation of lignin by the mild oxidation of earbohydrates with potassium periodate (Ritchie and Purves, Pulp and Paper Mag. Canada, 48, No. 12, 74; 1947; Wald, Ritchie and Purves, J. Amer. Chem. Soc., 69, 1371; 1947). This isolated lignin formed the basis of much subsequent work on the mechanisms of reactions related to tho processes of the pulp and paper industry.

At McGill alone, more than a hundred students received their doctorate degrees under the tutelage of Dr. Purves. Many of them have now themselves achieved prominence in universities, government and industry.

Dr. Purves assumed tho chairmanship of the Department of Chemistry in 1961, and under his administration the Department grew in the number and quality of its staff. But his chief task during the past four years was to supervise the planning and construction of the new Chemistry Building, named in memory of his long-time colleague, Prof. Otto Maass. That building now stands as a memorial to both of them.

Henry I. BotKer 